\title{
Reinstatement and Rediagnosis of Catapaguroides setosus and Description of a Second Hawaiian Species of the Genus (Decapoda: Anomura: Paguridea: Paguridae) ${ }^{1}$
}

\author{
Patsy A. McLaughlin ${ }^{2}$ and Cory Pittman ${ }^{3}$
}

\begin{abstract}
A species of the hermit crab genus Catapaguroides recently discovered in a sand-dwelling Halimeda community on the island of Maui, Hawaiian Islands, prompted a reexamination of the holotype of Catapaguroides setosus (Edmondson, 1951), described from off the south coast of O'ahu. The latter species, currently considered a junior subjective synonym of Catapaguroides fragilis (Melin), is herein adjudged neither synonymous with $C$. fragilis nor conspecific with the second Hawaiian species. Catapaguroides setosus is reinstated with full specific rank, rediagnosed, and illustrated. The second species, Catapaguroides hooveri McLaughlin \& Pittman, n. sp., is described and illustrated.
\end{abstract}

As PART OF THE bycatch of a 1998-1999 survey of Hawaiian opisthobranch mollusks at a site $1.6 \mathrm{~km}$ north of Keka'a Point, on the island of Maui, Hawaiian Islands, the attention of one of the authors (C.P.) was drawn to a colorful, fast-moving, tiny hermit crab. Several very small hermit crab species are known from the shallow waters of the Hawaiian Islands (e.g., Edmondson 1951, McLaughlin and Haig 1984, McLaughlin 1986); however, this is the first species recognized exclusively from the sand-dwelling Halimeda community. This hermit crab has been found to represent an undescribed species of the genus Catapaguroides A. MilneEdwards \& Bouvier, 1892.

In her revision of the genera Catapaguroides and Cestopagurus, de Saint Laurent (1968) transferred the Hawaiian Cestopagurus setosus Edmondson, 1951, to the genus Catapaguroides, and placed it in synonymy with Catapaguroides fragilis (Melin, 1939). De Saint

1 This is a scientific contribution from the Shannon Point Marine Center, Western Washington University. Manuscript accepted 20 March 2001.

2 Shannon Point Marine Center, Western Washington University, 1900 Shannon Point Road, Anacortes, Washington 98221-9081B (E-mail: patsy@sos.net).

${ }^{3}$ P.O. Box 23, Fairfield, Washington 99012.

Pacific Science (2002), vol. 56, no. 1:41-48 (C) 2002 by University of Hawai'i Press. All rights reserved
Laurent (1968) had compared Edmondson's (1951) male holotype with the "mutilated" male holotype of Melin's species and a small female collected from Mururoa. Although de Saint Laurent noted certain differences among the three, she provisionally considered all three to represent a single taxon. She illustrated only the right cheliped of the Mururoan specimen.

As noted by McLaughlin (2001), the holotype of Catapaguroides [as Eupagurus (Catapagurus)] fragilis is represented in the collections of the Museum of Evolutionary Zoology (MEZ), Uppsala, Sweden, by a series of 11 slides (MEZ $439 \mathrm{a}-\mathrm{k}$ ) of the antennules, antennae, first through third maxillipeds, right second pereopod, and right fifth pereopod. The body and detached left cheliped, in the collection of the Swedish Museum of Natural History, Stockholm (SMNH), represent the "mutilated" specimen (smnh Type-2291) examined by de Saint Laurent (1968). Neither Melin's (1939) specimen, nor the Mururoa specimen appear to be conspecific with Edmondson's (1951) taxon, the holotype of which is preserved in the collections of the Bernice P. Bishop Museum (врвм), nor with the new species described here.

\section{MATERIALS AND METHODS}

Opisthobranch sampling in the Halimeda beds consisted of two types. To sample the 
alga itself, a glove with paintbrush bristles attached to the fingers was swept by a diver though the clumps and the "plankton" generated was scooped into a $0.25-\mathrm{mm}$ mesh, tubular net. To sample the sand-dwelling species, the sand was either scooped or swept into a $1.0-\mathrm{mm}$ mesh sieve by the diver and sieved in the field, with the retained residue bagged for later examination under a dissecting microscope. The sieved hermit crabs were initially preserved in $10 \%$ formalin and later transferred to $70 \%$ ethyl alcohol for storage.

Catapaguroides setosus is herein rediagnosed from its holotype (still the only known specimen) and compared with $C$. fragilis and $C$. hooveri, n. sp. The holotype of $C$. hooveri, $\mathrm{n}$. sp., and the illustrated paratypes have been deposited in the collections of the National Museum of Natural History, Smithsonian Institution (USNM). Additional paratypes are deposited in the collection of the Bishop Museum. General terminology for the species diagnosis and/or description follows that of McLaughlin (1997). One measurement, shield length (sl), as measured from the midpoint of the rostral lobe to the midpoint of the posterior margin of the shield, provides an indication of animal size. The abbreviation ovig. indicates ovigerous females.

\section{SYSTEMATICS}

Catapaguroides setosus (Edmondson, 1951) Figure $1 A-D$

Cestopagurus setosus Edmondson, 1951:200, fig. 9.

Catapaguroides setosus: de Saint Laurent, 1968:941.

TYPE MATERIAL: Holotype $\hat{o}(\mathrm{sl}=1.6$ $\mathrm{mm}$ ), off south coast of $\mathrm{O}^{6} \mathrm{ahu}, 18 \mathrm{~m}$, врвм S5512.

DIAGNOSIS: Shield approximately as broad as long; rostrum broadly rounded, produced beyond level of lateral projections. Ocular peduncles slightly shorter than shield length; corneas very slightly dilated; ocular acicles acute, separated by slightly more than basal width of one acicle. Antennular peduncle (right missing) overreaching distal margin of cornea by approximately 0.35 length of ultimate segment. Antennal peduncle (right missing) reaching approximately to distal margin of cornea; dorsolateral distal angle of second peduncular segment elongate, reaching to proximal margin of fourth segment; dorsomesial distal angle with small spine.

Right cheliped considerably longer and stouter than left. Dactyl and fixed finger of right cheliped strongly arched ventrally. Dactyl articulating obliquely with palm; dorsomesial margin with prominent, thin ridge, dorsal surface with numerous long setae. Palm elongate, moderately slender proximally, broadening distally, dorsomesial margin with row of 4 moderately widely spaced spines, dorsolateral margin unarmed but with slightly elevated ridge, extending nearly entire length of fixed finger; lateral face weakly concave; dorsal surfaces of palm and fixed finger with numerous long setae. Merus with small spine at ventrolateral distal angle.

Left cheliped with dactyl and fixed finger somewhat arched ventrally. Dactyl 1.2 length of palm; unarmed but with numerous long setae. Palm moderately slender, approximately 0.6 length of carpus; dorsomesial margin with 4 small spines, dorsal surface with long setae. Carpus with 3 small spines on dorsomesial margin, dorsal surface with long setae.

Ambulatory legs (only right third remaining in vial) longer than right cheliped. Dactyl arched in distal half, slightly longer than propodus, terminating in slender, corneous claw, dorsal surface with row of long stiff setae. Propodi of second each with tuft of 3 or 4 stiff bristles or corneous spines (Edmondson 1951: fig. 9g); meri and ischia apparently all unarmed, but with tufts of long setae. Carpi, at least right third, with dorsodistal spinule.

Sternite of third pereopods roundly subquadrate. Right male sexual tube elongate, reaching beyond coxa of left fourth pereopod; left sexual tube very short. Telson with slightly asymmetrical, narrow, posterior lobes, separated by deep median cleft, terminal margins apparently unarmed.

REMARKs: The holotype of $C$. setosus is in poor condition, but it is clear from the remaining left antennal peduncle that Edmondson (1951: fig. $9 d$ ) inaccurately depicted 


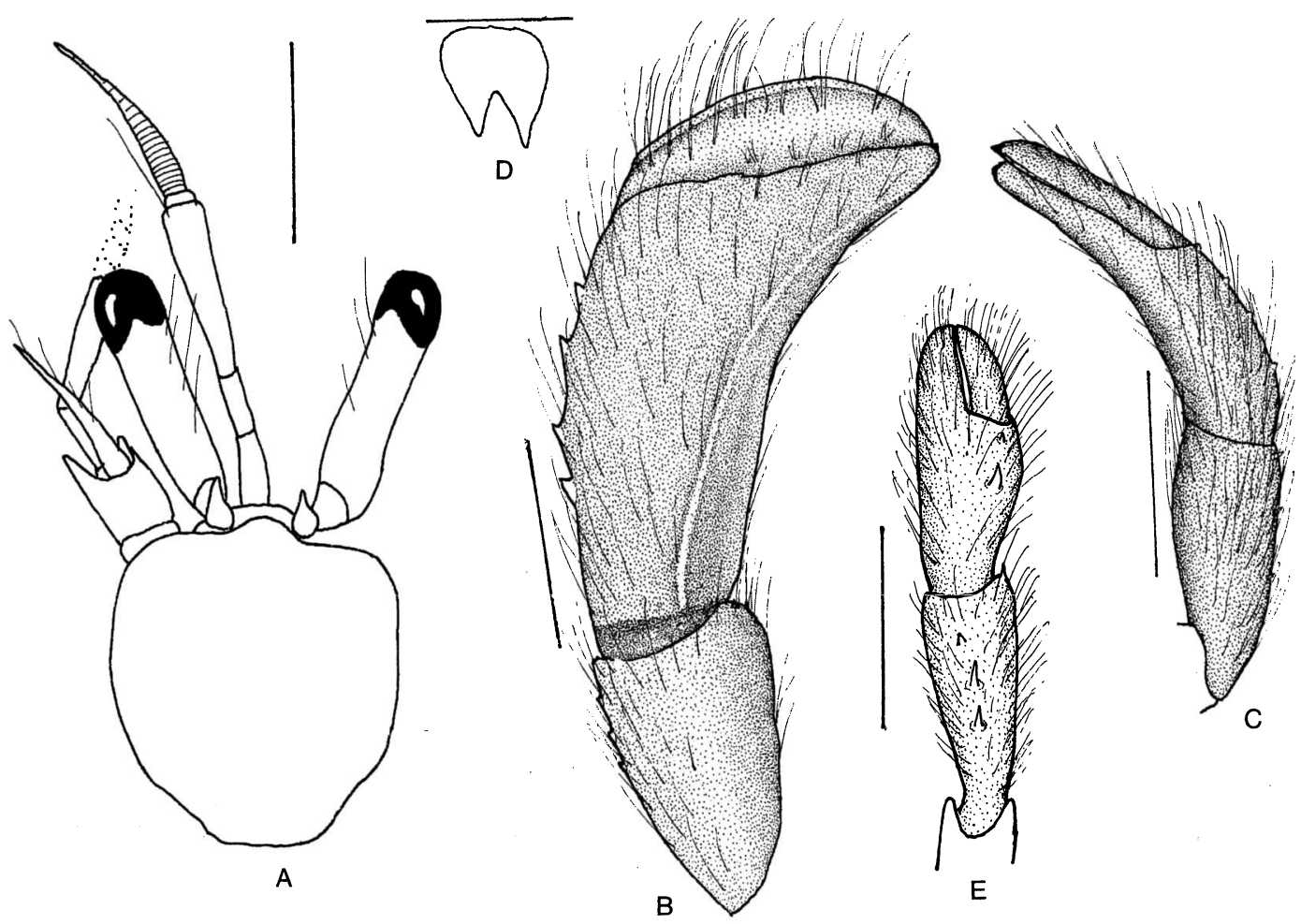

Figure 1. Catapaguroides setosus (Edmondson, 1951): $A-D$, holotype, вPвм S5512. $A$, shield and cephalic appendages (aesthetascs omitted); $B$, carpus and chela of right cheliped (dorsolateral view); $C$, carpus and chela of left cheliped (dorsolateral view); $D$, telson. Catapaguroides fragilis (Melin, 1939): holotype, smNH Type-2291. E, carpus and chela of left cheliped (dorsal view). Scales, $1 \mathrm{~mm}(A-C, E) ; 0.5 \mathrm{~mm}(D)$.

this structure. His peduncle appears to be four-segmented, and illustrated in mesial view. It shows the second and third segments combined as one. Similarly, the ultimate segment of the antennular peduncle is longer than shown in Edmondson's fig. 9c, and the posterior lobes of the telson are much narrower than illustrated in fig. 9i. As indicated in the diagnosis, the right and left cheliped, albeit detached, still have an abundance of setae.

De Saint Laurent (1968) remarked in her comparison of $C$. setosus and $C$. fragilis that the two holotypes were approximately the same size. The right cheliped of $C$. fragilis was missing, but the left chelipeds of it and $C$. setosus seemed quite similar. This is not entirely accurate. The dactyl of $C$. fragilis (Figure $1 E$ ) is appreciably shorter, in relation to the palm, than it is in $C$. setosus, and it and the fixed finger are not ventrally arched as they are in C. setosus. Melin's (1939) specimen has one small and one prominent spine on the dorsomesial margin of the palm, and three dorsomedian spines on the carpus. In addition, the ventromesial distal margin of the carpus has a small spine. In contrast, $C$. setosus has four small spines on the dorsomesial margin of the palm and three on the dorsomesial margin of the carpus; the ventromesial distal angle is unarmed.

We have found, as did de Saint Laurent (1968), appreciably greater differences between the illustrated right chela and carpus of the Mururoan specimen also attributed to $C$. fragilis and that of Edmondson's specimen. In C. setosus, for example, the dactyl has a prominent thin ridge on the dorsomesial margin. 
In $C$. fragilis from Mururoa, there is only a single small spine proximally. The dactyl and fixed finger of the Hawaiian species are strongly arched ventrally, but do not appear at all arched in the Mururoan specimen (de Saint Laurent 1968: fig. 26, as ? Catapaguroides gracilis [sic]). The shape of the palm differs markedly in the two specimens. In $C$. setosus, the palm is narrow proximally and widens distally at the base of the fixed finger. The width of the palm is approximately uniform from proximal to distal margins in $C$. fragilis from Mururoa. There is also a prominent spine on the dorsoproximal midline of the palm in the latter species that is not present in C. setosus. De Saint Laurent (1968) recognized these differences, but, because the specimen from Mururoa was a considerably smaller female, believed that size and sexual dimorphism could not be ruled out. Consequently she tentatively considered $C$. setosus, her Mururoan specimen, and Melin's (1939) C. fragilis conspecific. It is quite true that in several pagurid and diogenid genera, size and sexual dimorphism could account for the types of variation noted here. However, McLaughlin (2001) recently demonstrated that although strength of spination is variable within species of Catapaguroides, it does not appear to be influenced by size or sex. Therefore, we feel that there are sufficient differences between $C$. setosus and the other specimens attributed to $C$. fragilis to reinstate Edmondson's taxon.

Catapaguroides hooveri McLaughlin \& Pittman, n. sp.

Figure $2 A-H$

TYPE MATERIAL: Holotype: $\widehat{\sigma}(\mathrm{sl}=0.85$ $\mathrm{mm}), 1.6 \mathrm{~km}$ north of Keka'a Point, Maui, Hawaiian Islands, 16.8-18.2 m, 29 October 1998, collector C. Pittman, USNM 308989. Paratypes: $3 \hat{o}(\mathrm{sl}=0.92-1.20 \mathrm{~mm}), 1$ 우 $(\mathrm{sl}=0.85 \mathrm{~mm}), 2$ ovigerous + ( $(\mathrm{sl}=0.86,0.92$ $\mathrm{mm}), 1.6 \mathrm{~km}$ north of Keka'a Point, Maui, Hawaiian Islands, 16.8-18.2 m, 29 October 1998, collector C. Pittman, USNM 308990; 3 ๙ $(\mathrm{sl}=0.78-0.95 \mathrm{~mm}), 1$ ㅇ $(\mathrm{sl}=0.61 \mathrm{~mm}), 1$ ovigerous $\circ(\mathrm{sl}=0.88 \mathrm{~mm}), 1.6 \mathrm{~km}$ north of Keka'a Point, Maui, Hawaiian Islands, 11.3-
16.2 m, 3 June 1999, collector C. Pittman, BPBM.

DESCRIPTION: Shield (Figure $2 A$ ) slightly longer than broad to slightly broader than long; anterior margin between rostrum and lateral projections weakly concave; anterolateral margins sloping, posterior margin truncate; dorsal surface with few moderately long setae. Rostrum broadly rounded. Lateral projections obtusely triangular, produced little if at all beyond level of rostrum; with small marginal or submarginal spinule.

Ocular peduncles moderately long and moderately stout, $0.75-0.85$ shield length; few moderately short setae on dorsal surfaces; corneas somewhat cone-shaped. Ocular acicles small, triangular, with submarginal distal spine.

Antennular peduncles overreaching ocular peduncles by at least $0.70-0.95$ length of ultimate peduncular segment. Basal segment elongate, with slender, acute spine dorsally on statocyst lobe, ventral surface with few long setae. Penultimate segment with few scattered short setae. Ultimate segment with 2 very long distally plumose or pinnate setae.

Antennal peduncles moderately long, reaching beyond basal and frequently distal margins of corneas. Fifth and fourth segments with few scattered setae. Third segment with few setae and acute spine at ventrodistal margin. Second segment with dorsolateral distal angle produced, terminating in prominent simple or bifid spine, occasionally with accessory spinule on mesial margin; dorsomesial distal angle with small spine. First segment unarmed or with 1 spinule on ventrolateral margin. Antennal acicle slender, arcuate, reaching beyond proximal margin of ultimate peduncular segment; terminating in slender spine and with several long setae distally. Antennal flagella (missing in holotype) moderately short; with 1-4 moderate short to moderately long setae on each article, longest proximally.

Right cheliped (Figure 2B) with dactyl articulating obliquely with palm; propodalcarpal articulation rotated clockwise approximately $30^{\circ}$ from perpendicular. Dactyl 0.60 0.80 length of palm; cutting edge with 2 or 3 prominent calcareous teeth; terminating in small calcareous claw; dorsal surface 


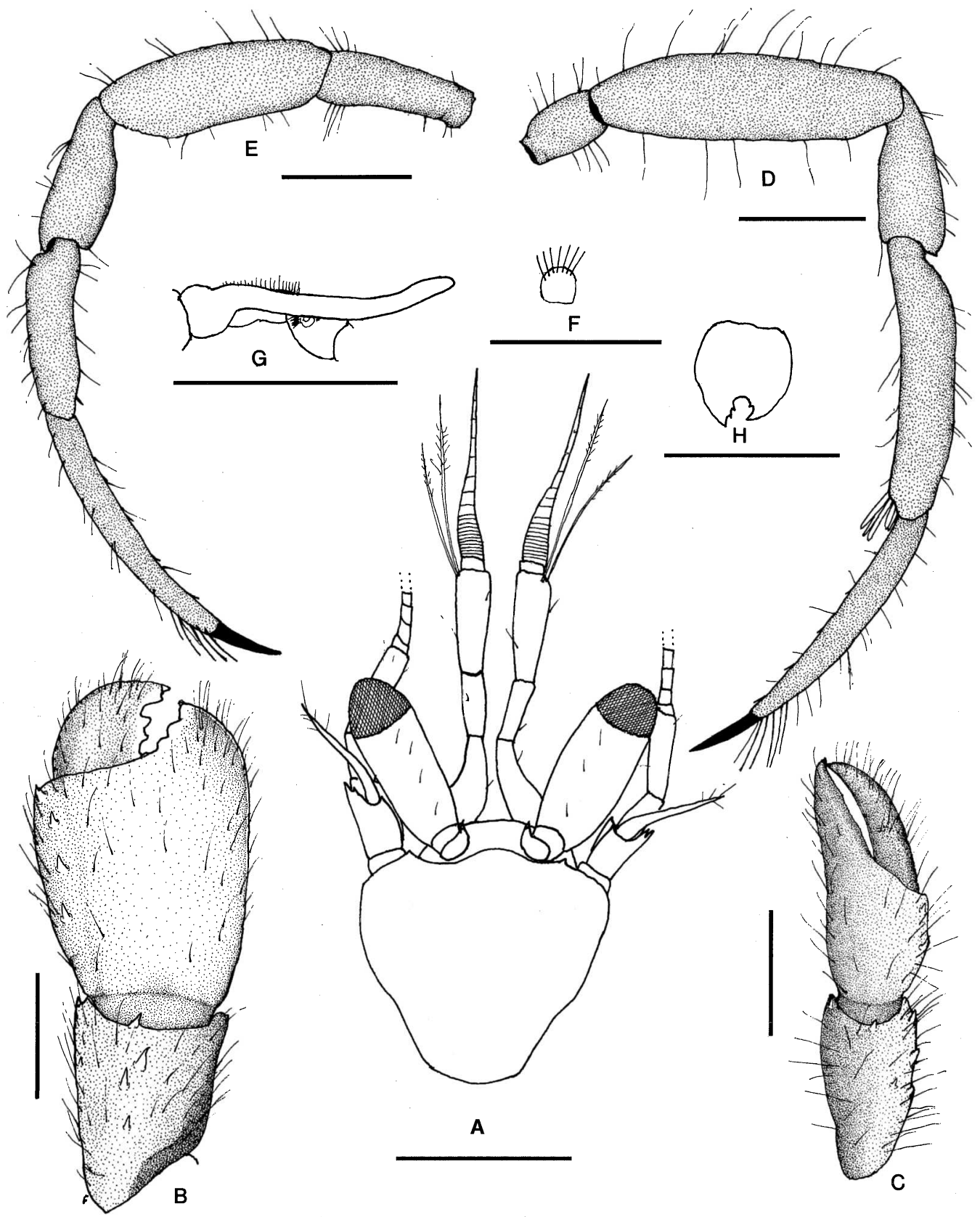

Figure 2. Catapaguroides booveri McLaughlin \& Pittman, n. sp.: $A$, holotype, usnm $308989 ; B-G$, paratype $\widehat{\jmath}(\mathrm{sl}=0.92$ $\mathrm{mm})$, USNM $308990 ; H$, second paratype $\sigma^{\hat{\sigma}}(\mathrm{sl}=0.92 \mathrm{~mm})$, USNM 308990 . $A$, shield and cephalic appendages (aesthetascs omitted); $B$, carpus and chela of right cheliped (dorsal view); $C$, carpus and chela of left cheliped (dorsal view); $D$, second right pereopod (lateral view); $E$, third left pereopod (lateral view); $F$, anterior lobe of sternite of third pereopods; $G$, coxae and sternite of fifth pereopod (ventral view); $H$, telson. Scales, $0.5 \mathrm{~mm}$. 
microscopically granular, slightly elevated and broadly rounded proximally, dorsomesial margin drawn out into weak, faintly crenulate, or somewhat spinulose ridge, armature strongest proximally; mesial and ventral surfaces with scattered, moderately long setae. Palm equal to or slightly longer than carpus; dorsomesial margin with 4 or 5 moderately large, acute spines, dorsal surface of palm and fixed finger convex, dorsolateral margin delimited distally on palm and entire length of fixed finger as faintly elevated, minutely granular ridge; mesial face and ventral surface of palm and fixed finger with scattered setae; cutting edge of fixed finger with 2 or 3 prominent calcareous teeth, terminating in small calcareous claw. Carpus approximately equal to length of merus; dorsomesial distal angle with small, acute spine, few long setae on dorsomesial margin, sparse long setae on dorsal surface and dorsolateral margin, dorsal surface mesiad of midline occasionally with 1 small spine, surface laterad of midline with row of 4 or 5 spines, ventrally sloping dorsolateral surface microscopically granular; mesial, lateral, and ventral surfaces with scattered long setae, most numerous ventrally. Merus subtriangular; dorsal margin with few long setae; ventromesial margin with 2-4 prominent spines distally and row of long setae; ventrolateral margin with 1 or 2 prominent spines near distal angle and row of long setae. Ischium with long setae dorsally and ventrally.

Left cheliped (Figure $2 C$ ) reaching beyond proximal margin of dactyl of right; with propodal-carpal articulation twisted $15-30^{\circ}$ counterclockwise from perpendicular; dactyl and fixed finger curved ventrally and often with distinct hiatus. Dactyl 1.10-1.25 longer than palm, unarmed but with scattered, long setae; cutting edge with row of minute corneous teeth. Palm approximately 0.75 length of carpus; dorsomesial margin with 2 small spines and long setae, dorsal surface of palm unarmed, but with scattered long setae, fixed finger also unarmed, but with scattered long setae; dorsolateral margin not delimited. Carpus approximately equal to length of merus; dorsomesial distal angle usually with small spine, dorsomesial margin with 2 or 3 spines and numerous long setae; dorsolateral distal angle with 1 small spine, dorsolateral margin not delimited; ventrolateral distal angle with prominent spine; mesial and ventral surfaces with scattered, long setae. Merus with few long setae on dorsal margin; ventrolateral margin with 1 or 2 slender spines in distal half; ventromesial margin unarmed or with 1 spine in distal half. Ischium unarmed, but with several long setae.

Ambulatory legs (Figure 2D,E) elongate, overreaching right cheliped by approximately half length of dactyls; terminating in long, slender claws. Dactyls 1.25-1.75 length of propodi; in dorsal view, straight; in lateral view, slightly curved ventrally, surfaces with few long and short setae, 4 or 5 thicker, long setae dorsally toward distal margin; ventral margins each with 4 slender, widely spaced corneous spinules. Propodi of second pereopods each with 3-5 moderately short, thick, stiff, articulated bristles at ventrodistal margin (males) or unarmed (females); propodi of third pereopods each with ventrodistal margins unarmed or with 1 short corneous spinule; dorsal and ventral surfaces all with scattered, long setae. Carpi each with spinule at dorsodistal angle and few setae dorsally and ventrally. Meri and ischia each with scattered setae. Fourth pereopods with 3 or 4 denticles on ventral margin of dactyl; propodal rasp consisting of 6-8 corneous scales. Fifth pereopods semichelate. Sternite of third pereopods with roundly subquadrate anterior lobe (Figure $2 F$ ); anterior margin with row of moderately long setae.

Male with long sexual tube emanating from coxa of right fifth pereopod (Figure $2 G$ ), directed from right to left and reaching beyond coxa of left fifth pereopod; coxa of left with short sexual tube directed from left to right, not obscured by adjacent tufts of setae.

Telson (Figure $2 H$ ) with asymmetrical posterior lobes separated by deep median cleft; terminal margins each with 1-3 small acute spines; lateral margins each delimited by chitinous plate.

COLOR: In life, shield and posterior carapace red; ocular peduncles with reddish band proximally. Chelipeds white with patches of red. Ambulatory legs banded dark bluish purple and white. 
HABIтAT: Found in sand samples collected between clumps of Halimeda, rather than in sweeps of the alga itself.

AFFINITIES: In having somewhat reduced and cone-shaped corneas, Catapaguroides booveri, n. sp., appears most closely allied to C. foresti McLaughlin, 2001, described from Guam, and the cosmopolitan C. microps A. Milne-Edwards \& Bouvier, 1892. The considerably shorter ocular peduncles with markedly reduced corneas of $C$. microps and its entirely unarmed right cheliped will immediately distinguish $C$. microps from both the Guam species and $C$. hooveri. Catapaguroides booveri is distinguished from $C$. foresti by the differences in cheliped armature, particularly the left chela and carpus that are completely unarmed in the Guam species. In addition, the ocular peduncles of $C$. hooveri are stouter; the ultimate segment of the antennular peduncle and the antennal acicle also are appreciably shorter.

The shape and armature of the chelipeds of $C$. hooveri are similar to those of $C$. setosus; however, the right cheliped of the former species is not as noticeably narrowed proximally. However, the stout ocular peduncles with cone-shaped corneas of $C$. hooveri clearly set this species apart from Edmondson's (1951) taxon. Other distinguishing characters of $C$. hooveri include the shorter ultimate segments of the antennular peduncles; the telson, which is armed on each of the nearly perpendicular terminal margins with one to three spines; and the appreciably less-dense setation.

ASSOCIATIONS AND BEHAVIOR: In the context of the Halimeda community, C. hooveri is by far the most common hermit found in the sand patches between the clumps of $\mathrm{Hal}$ imeda. In contrast, the most common hermit crab found in sweeps of the alga is Calcinus laurentae Haig \& McLaughlin, 1984, with occasional occurrences of Micropagurus devaneyi McLaughlin, 1986, Anapagrides reesei (McLaughlin, 1986), and Calcinus latens Randall, 1840. Catapaguroides hooveri is a fastmoving, active species and, like some other fast crabs such as young Dardanus deformis (H. Milne Edwards, 1836), frequently abandons its shell and runs off if handled roughly.
It appears to be fairly indiscriminate in its choice of shells, sometimes even using segments of crustacean molts, hollowed-out segments of Halimeda, or other "atypical" substitutes.

REPRODUCTION: Two ovigerous females were collected during the October sampling. The eggs were few in number $(4-10)$ and quite large (0.38-0.52 mm diameter); all were in a relatively early stage of development. A single ovigerous female was collected in June 1999. The five eggs this female carried all were "eyed" and measured between 0.38 and $0.55 \mathrm{~mm}$ in diameter. The size of the eggs and their scarcity in number suggest an abbreviated mode of development in this species.

DisTRIBUTION: Currently known only from the north side of Keka'a Point to $1.6 \mathrm{~km}$ north, Maui, Hawaiian Islands.

ETYMology This species is dedicated to John P. Hoover, avid diver and underwater photographer, who has provided the world with a glimpse of the marine life of Hawai' $i$ through his books Guide to Hawaii's Fishes and Hawai'i's Sea Creatures. John has also provided both specimens and stimulating discussions for the authors that have called our attention to some of Hawai'i's most interesting hermit crabs.

\section{ACKNOWLEDGMENTS}

We deeply appreciate the assistance of $\mathrm{Lu}$ Eldridge for enabling one of us (C.P.) to examine the holotype of $C$. setosus at the Bishop Museum.

\section{Literature Cited}

Edmondson, C. H. 1951. Some central Pacific crustaceans. Occas. Pap. Bernice P. Bishop Mus. 20 (13): 185-243.

Haig, J., and P. A. McLaughlin. 1984. New Calcinus species (Decapoda: Anomura: Diogenidae) from Hawaii, with a key to the local species. Micronesica 19 (1-2): 107-121.

McLaughlin, P. A. 1986. Three new genera and species of hermit crabs (Crustacea, Anomura, Paguridae) from Hawaii. J. Crustacean Biol. 6 (4): 789-803. 
1997. Crustacea Decapoda: Hermit crabs of the family Paguridae from the KARUBAR cruise in Indonesia. In A. Crosnier and P. Bouchet, eds. Résultats des Campagnes MUSORSTOM, 16. Mem. Mus. Natl. Hist. Nat. 172:433572.

. 2001. A new species of the genus Catapaguroides (Decapoda: Anomura: Paguroidea: Paguridae) from Guam, Micronesia. Crustaceana (Leiden) (in press).

McLaughlin, P. A., and J. Haig. 1984. A review of Pagurixus (Decapoda, Anomoura, Paguridae) and descriptions of new species. Crustaceana (Leiden) 47 (2): 121-148.

Melin, G. 1939. Paguriden und Galatheiden von Prof. Dr. Sixten Bocks Expedition nach den Bonin-Inseln 1914. Kongl. Sven. Vetenskakad. Handl. (3) 18 (2): 1119.

Milne-Edwards, A., and E. L. Bouvier. 1892. Observations préliminaires sur les paguriens recueillis par les expéditions du Trav- ailleur et du Talisman. Ann. Sci. Nat., Zool. Paleont. (7) 13:185-226.

Milne Edwards, H. 1836. Observations zoologiques sur les Pagures et description d'un nouveau genre de la tribu des Paguriens. Ann. Sci. Nat. Zool., Paris (2) 6:257-288.

Randall, J. W. 1840. Catalogue of the Crustacea brought by Thomas Nuttall and J. K. Townsend, from the west coast of North America and the Sandwich Islands, with descriptions of such species as are apparently new, among which are included several species of different localities, previously existing in the collection of the Academy. J. Acad. Nat. Sci. Phila. 8:106147.

Saint Laurent, M. de. 1968. Révision des genres Catapaguroides et Cestopagurus et description de quatre genres nouveaux. I. Catapaguroides A. Milne Edwards et Bouvier et Decapbyllus nov. gen. (Crustacés Décapodes Paguridae). Bull. Mus. Natl. Hist. Nat. (2) 39 (5) (1967): 923-954. 